\title{
Miranda
}

Revue pluridisciplinaire du monde anglophone /

Multidisciplinary peer-reviewed journal on the English-

speaking world

15 | 2017

Lolita at 60 / Staging American Bodies

\section{Another Walker Evans}

Centre national d'art et de culture Georges Pompidou, Paris, 26 April-14

August, 2017

Daniel Huber

\section{OpenEdition}

\section{Journals}

Electronic version

URL: http://journals.openedition.org/miranda/10920

DOI: 10.4000/miranda.10920

ISSN: 2108-6559

Publisher

Université Toulouse - Jean Jaurès

Electronic reference

Daniel Huber, "Another Walker Evans", Miranda [Online], 15 | 2017, Online since 03 October 2017,

connection on 16 February 2021. URL: http://journals.openedition.org/miranda/10920 ; DOI: https:// doi.org/10.4000/miranda. 10920

This text was automatically generated on 16 February 2021.

\section{cc) (i) (9)}

Miranda is licensed under a Creative Commons Attribution-NonCommercial-NoDerivatives 4.0

International License. 


\title{
Another Walker Evans
}

\author{
Centre national d'art et de culture Georges Pompidou, Paris, 26 April-14
}

August, 2017

\section{Daniel Huber}

1 Walker Evans has been in vogue in France recently, and it is yet "another Walker Evans" ${ }^{1}$ visitors could discover at the exhibition at the Centre Georges Pompidou between 26 April and 14 August, 2017. The Walker Evans exhibition, curated by Clément Chéroux, Senior Curator of Photography at the San Francisco Museum of Modern Art, is Evans' first major retrospective in France and signals an innovative departure in the appreciation of his œuvre. ${ }^{2}$ The photographs on view represented the very best of his career: the 300 original prints came from the greatest public and private collections from all around the world such as the two giants from New York, the Metropolitan Museum of Art (the Met), which conserves his archives, and the Museum of Modern Art (the MoMA), as well as the J. Paul Getty Museum of Los Angeles among others. This is a great feat in itself, but the exhibition showed much more than his photographs: the title Walker Evans was literally to be understood to stand for his work in its broadest context. As will be argued below, this exhibition follows on naturally from and extends the exhibition that was presented at Les Rencontres de la Photographie in Arles between 6 July-20 September 2015 ${ }^{3}$. Walker Evans will be shown at the San Francisco Museum of Modern Art between 23 September 2017 and 4 February 2018.

2 Evans is a key figure of the history of $20^{\text {th }}$ century American photography, both for his work and his thinking on the medium of photography. Reactions to his thinking and to his work imbue photographic practice and theory about the role of photography to this day. His work can be characterized as a visual quest for the essence of the identity of vernacular American culture, this everyday culture that is utilitarian in its productions, popular in its origins and amateur, domestic, home-made, in its practice and technique of execution (Chéroux 2017b: 9). It is possibly this desire to visually capture the identity of a culture, of a people, of a nation in constant change, this ultimately universal artistic subject, that makes his work appeal to later periods, our own in particular. His early career witnessed the Great Depression and its disastrous social and economic consequences in the 1930s: this forged his sensibility to adopt what came to be known 
as his "documentary style", which he later deployed in his work for Fortune and other magazines, a significant body of work that was lesser known until recently ${ }^{4}$, especially until David Campany's monograph in 2014 on his magazine work and the Arles exhibition in 2015, essentially built around Campany's research. Concerning the concept of the "documentary style", Evans said the following in his 1971 interview with Leslie Katz (Katz 1971: 87): "You see, a document has use, whereas art is really useless. Therefore art is never a document, though it certainly can adopt that style. ${ }^{5}$ According to Mora (2007: 10), it is this definition of the "documentary style" in art that became his greatest legacy, beyond his images themselves: the various interactions between subjectivity, objectivity, neutrality, realistic illusion; the photographic object and what it reflects of the world photographed; what the notion of the "photographic document" means. These are all reflections that have preoccupied photographers and theorists, in one way or another, for the past decades up to the present.

There were a number of important features in the scenography of the exhibition that will undoubtedly mark the future presentation of his ceuvre. ${ }^{6}$ What was a truly new departure in the organization of the material was a marked emphasis not only on his artistic output but also on what influenced him: more than one hundred original documents and objects on view revealed that he was an avid collector, of picture postcards of wooden churches and small-town main streets (especially those produced by the Detroit Publishing Company at the turn of the $20^{\text {th }}$ century), film and advertising posters, enamel shop-signs, pages from tool catalogues, press and police photographs, and other graphic objects and printed ephemera that had some connection with the America he witnessed. Indeed, a postcard size version of a contemporary film poster for Love Before Breakfast (1936, directed by Walter Lang and starring Carole Lombard) was pasted next to Evans' photograph (Figure 1) showing this poster on a hoarding separating the street from a row of houses in "Houses and Billboards in Atlanta" (1936). Similarly, he photographed "Main Street, from across railroad tracks, Morgan City, Louisiana, 1935" from the same vantage point as he found on a postcard in his collection but which considerably antedates the photograph. Anecdotes also report (Chéroux 2017b: 12) that in his later life he would often make away with the enamelled shop-sign that he had just photographed. There were also a couple of his oil paintings on view, of houses and aspects of main streets that Evans painted in the late 1950s (Figure 2). This concept of juxtaposing his collection and his production made for very fruitful associations between these items in his collection and his photographs in the neighbouring exhibition space. Indeed, the two rooms dedicated to his private collection were spaced so that related photographs were hung in a nearby room. It was one of the strong curatorial messages that in a way his photography could be regarded as the extension of his private collection and vice versa. This observation is identical in essence to what Evans said (Katz 1971: 85) when asked if there was any connection between what he collects and what he captures on film: "A great deal. It's almost the same thing." 
Figure 1

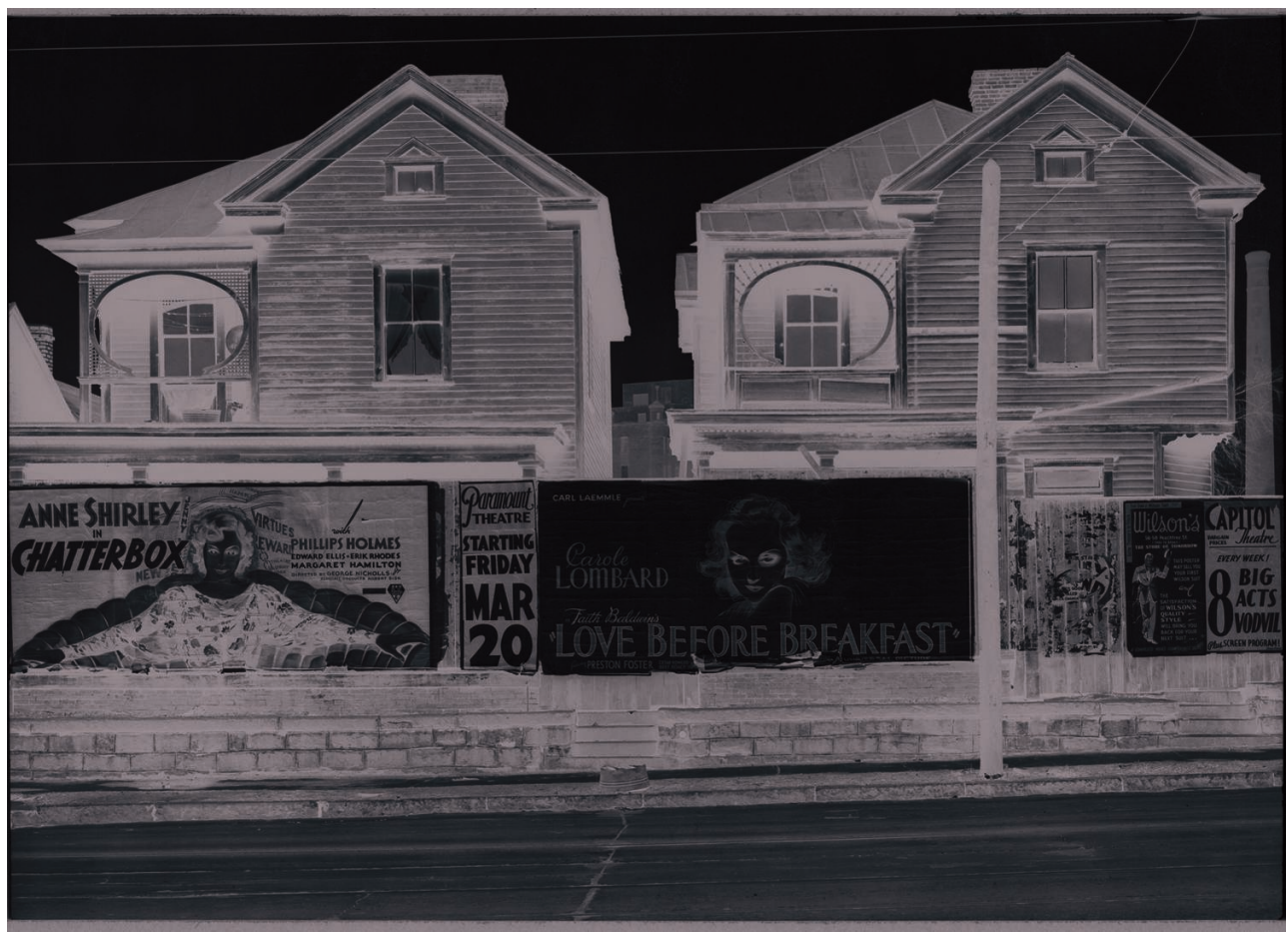

Houses and Billboards in Atlanta, 1936

Gelatin silver print, $16,5 \times 23,2 \mathrm{~cm}$

The Museum of Modern Art, New York

(c) WALKER EVANS ARCHIVE, THE METROPOLITAN MUSEUM OF ART

PHOTO : (C) 2016. DIgITAL IMAgE, THE MUSEUM OF MODERN ART, NEW YORK / SCALA, FLORENCE 
Figure 2

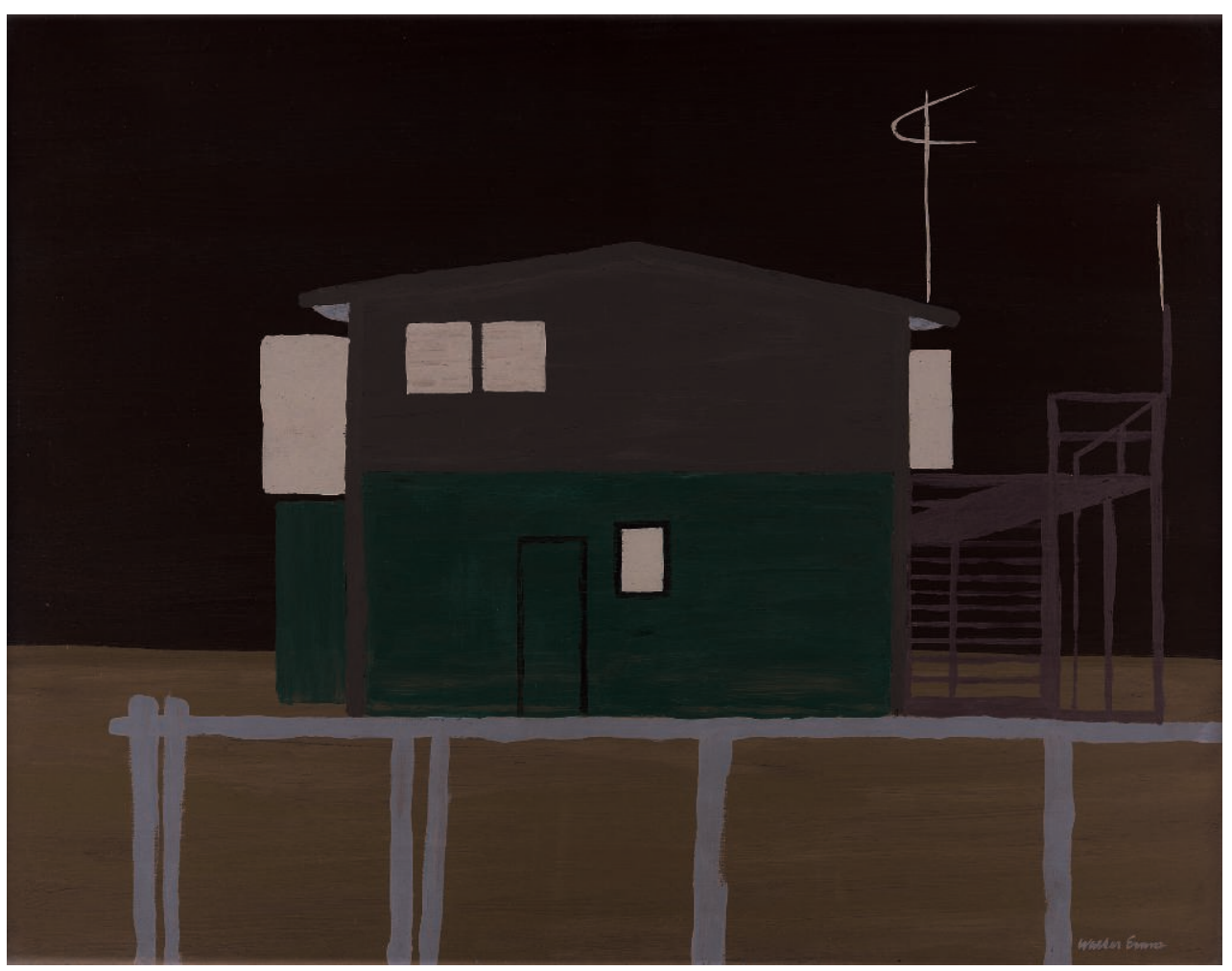

Anna Maria, Florida, October 1958

Oil on fibreboard

$40 \times 50,2 \mathrm{~cm}$

The Metropolitan Museum of Art, New York.

Walker Evans Archive, 1994, 1994.261.178

(C) WALKER EVANS ARCHIVE, THE METROPOLITAN MUSEUM OF ART

PHOTO () THE METROPOLITAN MUSEUM OF ART, DIST. RMN-GRAND PALAIS / IMAgE OF THE MMA

4 Another original element was the presentation of the material around the themes he photographed rather than in a chronological order. As Chéroux in his introductory essay (Chéroux 2017b: 9) explains, the whole conception of the show is based on the idea that the work of Walker Evans broke with the logic of a photograph being a synchronic entity coherent in space and time in the sense that his career demonstrated that he used his photographs to support his message, independently of their place and time of taking, and that this is in itself a truly vernacular approach to photography. The conception of the exhibition thus breaks with a chronological presentation and is constructed around themes, blending time and space (Chéroux 2017b: 9). This principle is justified and significantly more fruitful for the appreciation of his œuvre, and one can easily agree, because it resolves a number of problems related to Evans' career. For instance, he had a preference to draw on his earlier work for his later projects, and museal presentations habitually hesitate where to place the individual image, at the time of its taking or at another time, while in fact this problem did not even pose itself for Evans. Chéroux (ibid.) cites as an example the portraits he took on the underground in New York: they were taken between 1938 and 1941 but they were not published at the time and they took their final form in 1966 when they were presented at the MoMA and published in Many Are Called. To the curator, the question is whether to present this series as the continuation of his interest in the human face, begun in Alabama in the 1930s, or as a fine example among his more conceptual work for Fortune in the 1960s: 
whereas of course the material combines the two aspects. While the exhibition did follow a rough chronology in the order of introduction of the individual themes, within each topic one could find photographs taken at various points in his career. This organization emphasized the persistence of many topics throughout his career that would have more easily been lost to the visitor in a purely chronological presentation of the material, and made effective comparison possible. This was a new departure for the appreciation of Evans' work because one of the consequences of this curatorial position was that there was no specific mention in the accompanying texts in the exhibition space of specific book publications, such as his first and thoroughly influential volume American Photographs, presented at the MoMA in 1938 and published in the same year. Instead, a generous selection of images from this specific body of work from the 1930s were to be found in the various themes. The specific topics covered in the exhibition included his trip to Paris in the late 1920s, roadside shacks and store fronts, window displays and signs, portraits of anonymous passers-by, that is "ordinary", people, signs of urban decay, the place of photographs in the home and in society, and so forth. These were all essential aspects of what he saw as "Americanness", or the "American vernacular".

5 A further feature of the presentation of the material was the conscious and frequent inclusion of his work as they had appeared in magazines, notably in Fortune between 1945 and 1965 and in Architectural Forum between 1958-62, among others. This has thus incidentally confirmed the success of the concept of the Arles exhibition in $2015^{7}$ and the publication of Walker Evans The Magazine Work by David Campany in 2014. In connection with the magazine work, it was also a welcome gesture that the material included some original portfolios that had not been shown in their entirety in the Walker Evans, Anonymous exhibition in Arles: their inclusion here made sure no visitor could have the impression of seeing an identical showing of these photo-essays. Also, there was at least one portfolio spread on view at the Centre Pompidou that was not presented in Arles: Primitive Churches. Out-of-the-way vignettes of US religious life (in Architectural Forum, December 1961). An additional novelty of the presentation was the inclusion of multimedia material such as excerpts from a 1975 interview with Annie Mae Burroughs, and an interactive free app that contained extra content in connection with some twenty photographs of his.

\section{Vernacular America as subject}

The exhibition began with his time spent in Paris in 1926-27. ${ }^{8}$ He had studied French literature at Williams College, one of the most prestigious private universities in Liberal Arts, in Williamstown, Massachusetts, between 1922-23. He then took a job at the New York Public Library in 1924 where he immersed himself in the latest publications of modernism (Campany 2014: 10). He came to this "incandescent centre" of the arts that was Paris, in April 1926 to study the language and French literature and civilisation: he took out a pension at 5 rue de la Santé and took courses at the Sorbonne and at the Collège de France and tried his hand at translating Baudelaire's prose poems ("La chambre double" and "À une heure du matin") and an excerpt, published with the title "Mad", from Moravagine by Blaise Cendrars ${ }^{10}$ and avidly read French authors. In his long interview with Leslie Katz in 1971 (Katz 1971: 84, also quoted in Campany 2014: 39, and footnote 102), he talked about this influence: “...Flaubert's esthetic is absolutely mine. 
Flaubert's method I think I incorporated almost unconsciously, but anyway used it in two ways: his realism and naturalism both, and his objectivity of treatment; the nonappearance of the author, the non-subjectivity. (...) But spiritually, however, it is Baudelaire who is the influence on me. (...) Baudelaire influenced me and everybody else too...". A collection of Evans' early self-portraits and other photographs were shown here together with very interesting, rarely seen, objects such as his typewritten homework for his "cours de civilisation" dated 17 November 1926.

7 His stay in Paris made him familiar not only with a whole manner of literary trends and figures but with photography too, especially the possibilities explored by European modernist photography. The photographs he started producing at this early period and after his return to New York in 1928 conform to the aesthetics of what would come to be known as the "classical" modernism of New Vision as practised by Rodchenko and theorized by Moholy-Nagy: photo-booth self-portraits (in 1929) in the manner of the Surrealists fond of automatism in art production, extreme close-ups, low and high angle shots, misframing, double exposures and superimpositions and an overall graphic effect that had nothing to do with pictorialism. Many of these early, modernist images were published as series or photo-reports in various magazines, such as Creative Art or Hound and Horn.

It was from 1931 onwards that he started to reveal his interest in the utilitarian and domestic nature of popular culture. What made him move away from modernism in its classical form and discover the vernacular was two crucial encounters in his life. In 1929 Berenice Abbott showed him the photographs Eugène Atget took throughout his life in Paris. The juxtaposition of Atget's photograph of the "Marchand d'abat-jours" ("Lampshade merchant", Paris, 1899-1900) and Evans' "Organ Grinder Street Musician" (New York, ca. 1929) brought out the connection between the two. Then in 1931 Lincoln Kirstein invited Evans to accompany him and to photograph Victorian architecture in New England.

One of his fascinations with the vernacular was small retailers' window displays and store fronts in general. He was interested in multiple aspects of these displays: the typography of the signs (Figure 3) and the painting of the store fronts themselves, how the owner marked the prices, how the mannequins looked, the care taken to arrange the products in the window, by form, by colour, by positioning, how merchandise spilt over onto the pavement-anything that evoked in him the poetics of these sights, the poetics of this essentially vernacular expression. As Chéroux (2017b: 11) formulates it, he was interested in how the utilitarian was transformed into the visible, in other words, how the utilitarian was made visible through use. Some of these photographs were published as photo-essays, for instance, The Pitch Direct (in Fortune, October 1958) or Collector's Items (written by Malcolm Bradbury, for Mademoiselle, 1963). He took more pleasure in the graphic quality of these store fronts than in what they actually served, namely commerce. In his text to The Pitch Direct, on view in its original spreads (also Campany 2014, Plates), he wrote about his position and aesthetic quest: "The stay-athome tourist (...) should approach the street fair without any reasonable intention, such as that of actually buying something. [...] one can get a lot of pleasure and rich and sensual enjoyment out of contemplating great bins of slightly defective tap wrenches, coils upon coils of glinty wire, and parabolas of hemp line honest and fragrant." He also noticed how the aspect of these window displays changed from one state to the next, and even from one neighbourhood to another. 
Figure 3

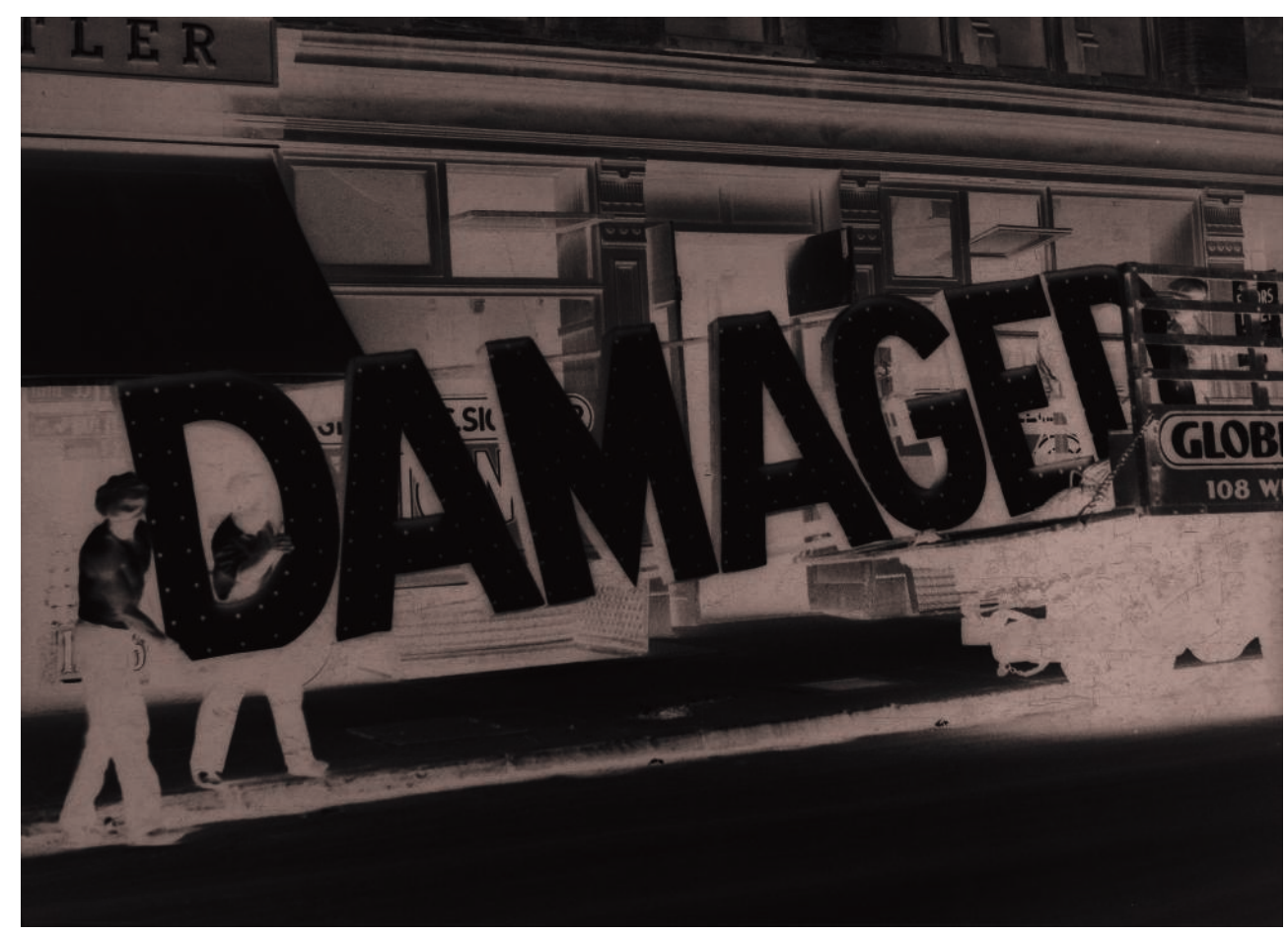

Truck and Sign, 1928-1930

Gelatin silver print, $16,5 \times 22,2 \mathrm{~cm}$

Private collection, San Francisco

(C) WALKER EVANS ARCHIVE, THE METROPOLITAN MUSEUM OF ART PHOTO : ( FERNANDO MAQUIEIRA, CROMOTEX

Store fronts were not only to be found in cities like New York, indeed, businesses were everywhere along the roads that helped build America: garages, snack bars, service stations, fruit and vegetable stands populated the roadside across the country. The main street attracted his attention throughout his career and he amassed a huge collection of postcards of main streets all across the United States. This pivotal centre of an American town, as opposed to a European one, organized around places of authority, featured in many of his photo-essays for Fortune magazine: the rhythm of the main street store fronts, the telegraph poles and the cars parked at an angle represented visual poetry for him (Figure 4). The roadside shacks and small shops represented an inexhaustible source of visual material to document and discover, and are in a very concrete sense the signals of what makes a consumer society, the American society first of all. 
Figure 4

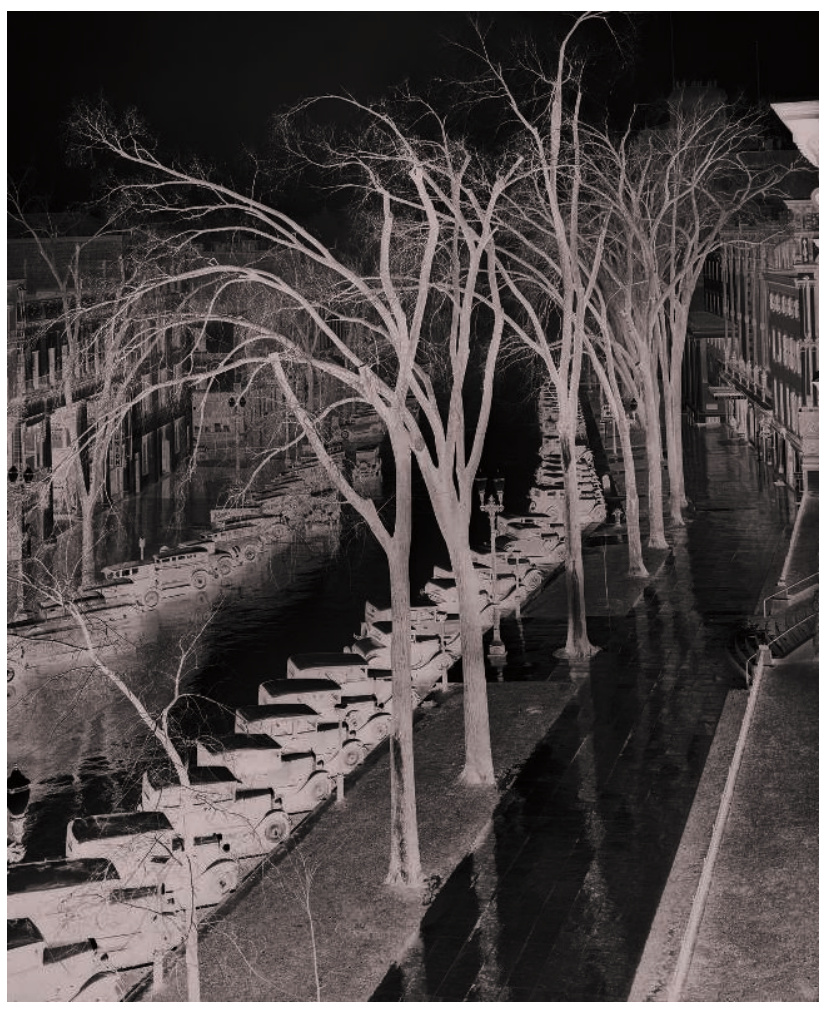

Main Street, Saratoga Springs, New York, 1931

Gelatin silver print, $18,73 \times 16,19 \mathrm{~cm}$

Private collection, San Francisco

(C) WALKER EVANS ARCHIVE, THE METROPOLITAN MUSEUM OF ART PHOTO : ( FERNANDO MAQUIEIRA, CROMOTEX

11 Evans' father was an advertising agent, which can partly explain his attraction, or at least his early exposure, to posters, hoardings, their vivid colours and slogans. Another connection is evident when one considers that he translated excerpts from the novel Moravagine by Blaise Cendrars, who had also been fascinated by the beauty of multicoloured posters. He photographed many hoardings, exterior advertising boards from the early 1930s onwards and included many in his work for the Farm Security Administration, when working on the effects of the Great Depression in the American South and Midwest. His aesthetic of documentation is visible in his manner of photographing these flat objects: sometimes from a frontal perspective and always in their context, an environment which is of course typically highly incoherent with the contents of the advertisement. Another set of more specific graphic elements Evans photographed were shop signs, boards, and signs in general, which he also photographed in their context and often close-up and frontally. As features of the truly vernacular aesthetic of the American cityscape, these signs were typically of the small trader, hand-painted and rudimentary. They nourished his visual appetite for logos, pictograms, and spelling mistakes, the latter of which he hunted down using colour Polaroids from 1973 until his death.

Besides specifically graphic aspects of his vernacular America, Evans was also interested in the people who inhabited this vernacular America. He took many photographs of people of humble background, share-croppers, manual workers, vagrants, and beggars. As he wrote in the opening sentences of his photo-essay People 
and Places in Trouble (in Fortune, March 1961, see Campany 2014, Plates), exhibited as original spreads from the magazine: "They speak with their eyes. People out of work are not given to talking much about the one thing on their minds." He took these portraits with his subjects perfectly conscious of his presence, indeed, they often participated in the construction of the image. In early 1937 the FSA sends him to Forrest City, Arkansas, to photograph the aftermath of the Mississippi River flood: and he photographed the racially segregated camps, the queues for food and the despair of those who had lost the little they had in a region that had already been hard hit by the dust storms and the drought of the preceding years. This would become his last assignment for the FSA. His approach to making portraits is perhaps most emblematically illustrated by his portraits of Allie Mae Burroughs, of which 4 negatives of 20x25cm survive (Figure 5). They were taken in Alabama in August 1936, when Evans shared the life and hardship of three share-cropper families, the Burroughs, Tengle and Fields families, for several weeks together with James Agee who was writing a report that would eventually become Let us Now Praise Famous Men (1941). Perhaps the rarest "exhibit" in the show was an interview recorded with Allie Mae Burroughs in 1975, and which was played in loop in one of the rooms, dedicated to her portraits as part of the portraits of the three Alabama families.

Figure 5

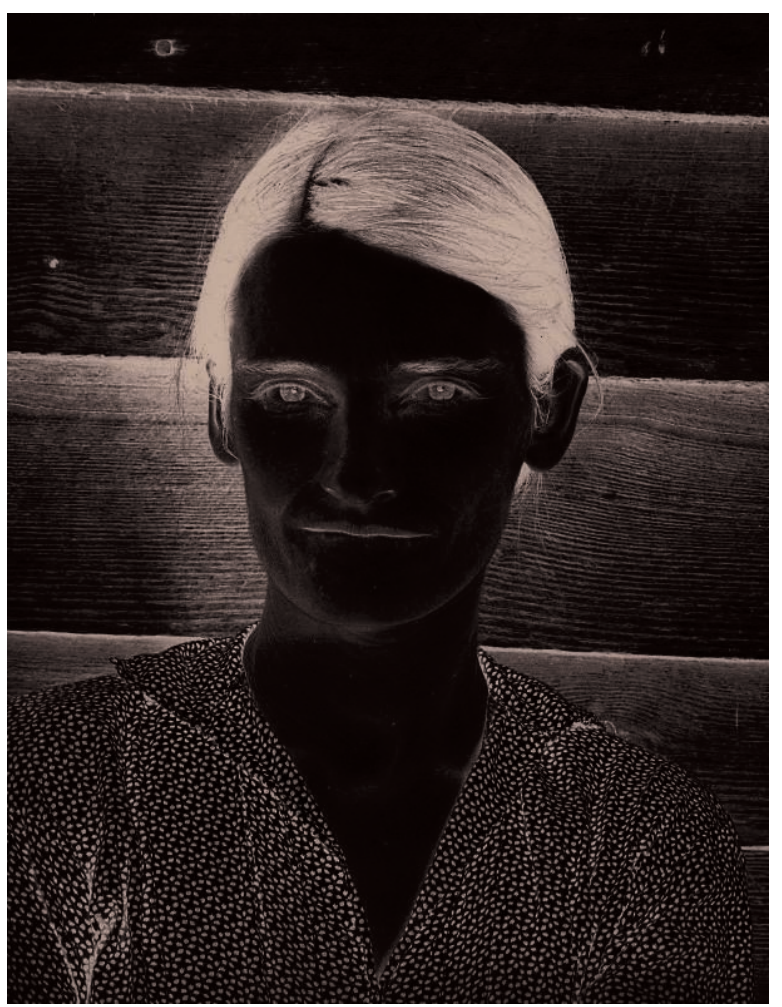

Allie Mae Burroughs, Wife of a Cotton Sharecropper, Hale Country, Alabama, 1936

Gelatin silver print, $22,3 \times 17,3 \mathrm{~cm}$

Private collection

(c) WALKER EVANS ARCHIVE, THE METROPOLITAN MUSEUM OF ART PHOTO : () PRIVATE COLLECTION

13 While Modernism in the United States is usually associated with the age of speed and skyscrapers, and the gleaming chrome of tools, Evans was attentive to the other side of 
progress, the underside of consumer society and mass production: unrestrained consumption brought ever-growing waste, and throughout his career he screened this development of American society. The result is a large body of work on urban decay from across his ceuvre: houses in ruin, faded interiors, crumpled metal. His photo-essays The Wreckers (in Fortune, May 1951), Color Accidents (in Architectural Forum, January 1958), and The Auto Junkyard (in Fortune, April 1962), among his very best on the subject, together with a selection of his images from the late 1920s and early 1930s, such as "Tin Relic" or "Stamped Tin Relic" (Figure 6), illustrated the point. The photo-essay The Auto Junkyard (1962) featured various Ford models at junk scrap piles, "the nether side of the automobile industry", left to abandon, while normally one could glimpse these cars either in the streets or in advertisements. "Scenes like these are rich in tragicomic suggestions of the fall of man from his high ride", he wrote. By the 1960s, his early interest in showing the downside of progress had culminated in photographs of junkyards, rubbish in gutters and dustbins: the logical final stages of accelerated consumption.

Figure 6

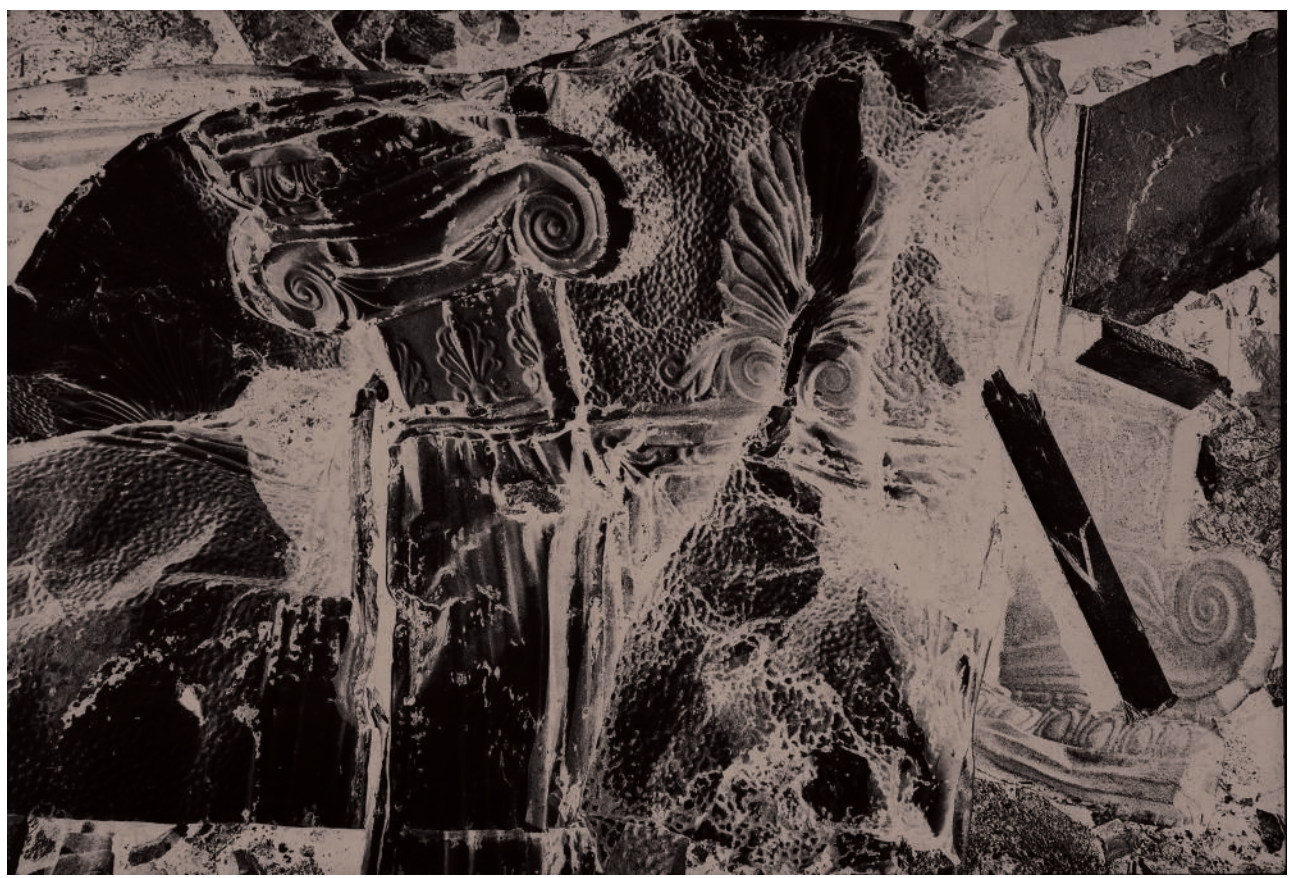

Stamped Tin Relic, 1929

Gelatin silver print, $23,3 \times 28 \mathrm{~cm}$

Collection Centre Pompidou, Paris, purchase in 1996

(c) Walker Evans Archive, The Metropolitan Museum of Art

Photo : (c) Centre Pompidou / Dist. RMN-GP

This section on the downside of progress also included his images that he took in Louisiana in 1935 of a "Louisiana Plantation House" and a "Room in a Louisiana Plantation House" when working for the FSA documenting the effect of the Great Depression. (One of these images was included in American Photographs in 1938.) This choice can be argued to be out of tune with the overall coherence of this section since the focus in these images is less on the decay of the plantation building itself and the state of abandon it suggests but rather on the anachronistic, so one would like to believe, survival of the architectural vestiges of an exploitative economic system, 
slavery and plantation economy, whose mentality was painfully illustrated in the 1937 Mississippi floods and for decades to come. Alpers (2017: 54) points out a different reason why these images are important: the empty room in this image, just like in others with furniture as in "Negro Barbershop Interior, Atlanta" or the numerous interiors in share-croppers' homes, almost suggests human presence without actually showing the inhabitants. Maybe such a group of photographs would have justified a section of their own showing empty, "vernacular" interiors that suggest human presence by their absence.

\section{The vernacular as method}

15 Walker Evans not only photographed elements of vernacular America, but in order to photograph his topics, he adopted non-artistic, that is vernacular, photographic approaches to his artistic projects (Chéroux 2017b: 12). When he set out to photograph the shining aspect of the chrome tool (Figure 7), as for his photo-essay Beauties of the Common Tool (in Fortune, July 1955), or when preparing the images for the MoMA exhibition catalogue on African Negro Art (spring 1935), he made himself a catalogue photographer. When he wanted to capture anonymous people passing by in the street, as in "Two Women Beneath a Store Awning" (August 1947), or those taken in Bridgeport in 1941, or Labor Anonymous (Detroit, 1946) or the images of people walking past taken in Chicago (used in two photo-essays: Edward Steichen's In and Out of Focus. Corner of State and Randolph Streets, Chicago, 1949, and Chicago. A camera exploration of the huge, energetic urban sprawl of the midlands, 1947), he took on the role of the street photographer. He followed an automatism that consisted in setting up his camera facing a fence or at a street corner and wait for anonymous Americans to walk into the frame. These series are not portraits and were never intended so. Indeed, Chéroux (2017b: 13) points out that this fascination for automatisms in making photographs no doubt owes much to Flaubert's aesthetic and the disappearance of the author. When he photographed elements of architecture, be it in the American South or New England, he became an architectural or postcard photographer for the project. But again, he chose not to choose a point of view, he systematically photographed from a frontal perspective, realist and impersonal. When he took the photographs of the site in Sarasota, Florida, where the Ringling Brothers Circus stored their old parade wagons, he proceeded like a forensic photographer at a crime scene photographing them from various angles, frontal, in profile, three-quarter view, in detail, in context. 
Figure 7

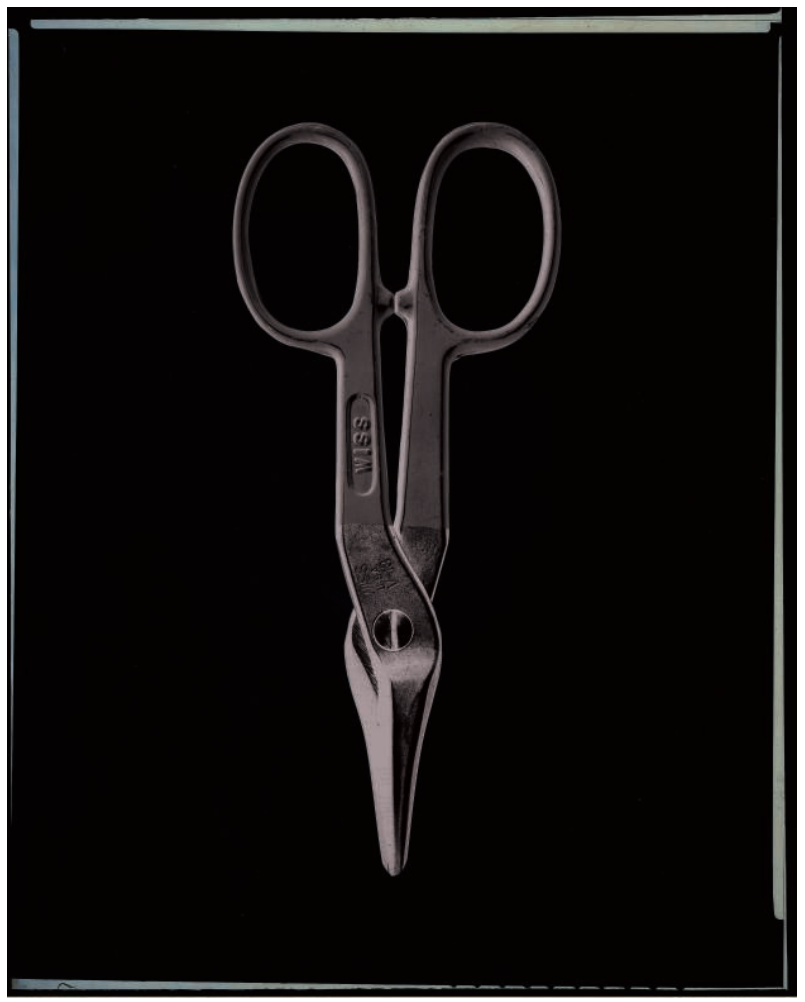

TIN SNIPS BY J. WISS AND SONS Co., \$ 1.85, 1955

GELATIN SILVER PRINT, 25,2 X 20,3 cM

THE J. PAUL GETTY MUSEUM, LOS ANgELeS

(C) WALKER EVANS ARCHIVE, THE METROPOLITAN MUSEUM OF ART

PHOTO : () THE J. PAUL GETTY MUSEUM, LOS ANgELES

16 This method is also evident in his photographs that have a meta-photographic character: he took his fellow-professionals for subjects when he photographed the display of a photo studio, a postcard display stand, family photographs on the wall, the street photographer and even a "Resort photographer at Work" (1941), Figure 8. Chéroux (2017b: 12) advances the position that in fact his style is not only "documentary" because he borrows from other visual registers as well such as that of snapshots, or picture postcards or advertising that have no real documenting function; it is Evans that uses them so. Therefore, he argues, it would be more appropriate to speak about "vernacular style" in his case. 
Figure 8

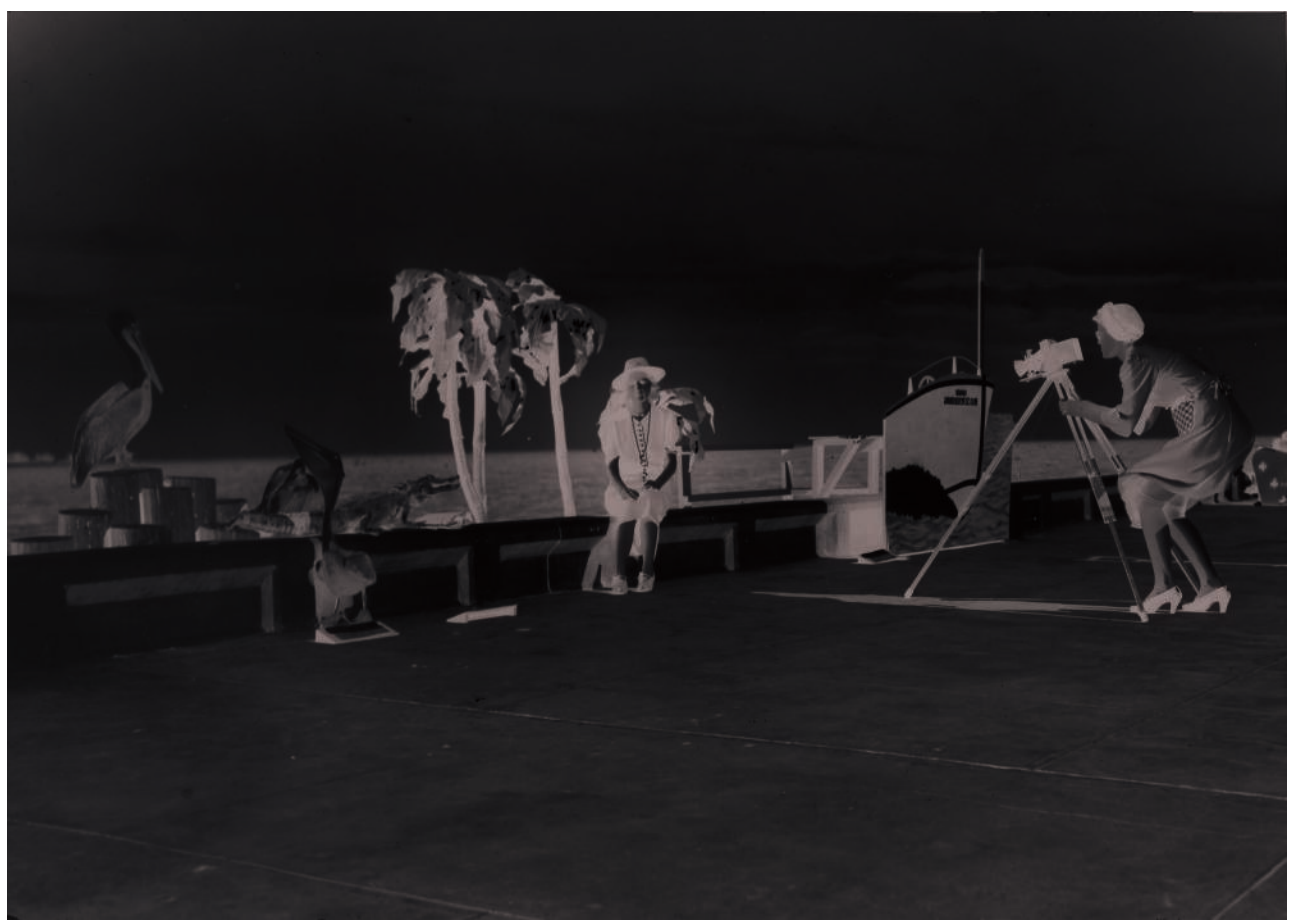

RESORT PHOTOgRAPHER AT WORK, 1941

GELATIN SILVER PRINT, LATER PRINT, 15,9 X 22,4 CM

THE J. PAUL GETTY MUSEUM, LOS ANgELES

(C) WALKER EVANS ARCHIVE, THE METROPOLITAN MUSEUM OF ART

PHOTO : (C) THE J. PAUL GETTY MUSEUM, LOS ANgELES

Whenever he photographed his topics, he systematically did it as an applied, that is professional, photographer would: he adopted a serial approach, which he then applied to his artistic and non-utilitarian projects. This aspect is evident in that impersonality, that repetition and lack of emphasis in his images. His fascination with means of transport, the railway carriage and the car in particular, did not only result in many images of the graphic splendour of these objects and their infrastructure, but also using, the train especially, as the viewpoint to photograph from: taking images looking through the window of a carriage in movement was an efficient method of satisfying his visual hunger for vernacular sights: store fronts, various signs, abandoned buildings and factories along the right-of-way. A combination of using a means of transport, the New York underground in this case, as the background and his method of taking pictures of those who came in range of the camera without much preparation had been applied in what would become known as his Rapid Transit: Eight Photographs series (taken between 1938-1941, published in The Cambridge Review, spring 1956) and The Unposed Portrait (in Harper's Bazaar, March 1962). All these aspects of his approach were at the opposite of what was expected in the practice of an artist-photographer, and he appropriated, as Chéroux (2017b: 12) puts it, the codes of vernacular photography well before the conceptual artists came to the fore in the 1960s. 


\section{BIBLIOGRAPHY}

Alpers, Svetlana. “L'œil d'Evans”. In Walker Evans. Exhibition catalogue. Editions du Centre Pompidou: Paris, 2017, pp. 51-55.

Bertrand, Anne. “'I'm a writer too.' Les textes de Walker Evans”. In Walker Evans. Exhibition catalogue. Editions du Centre Pompidou: Paris, 2017, pp. 39-44.

Campany, David (ed.). Walker Evans, The Magazine Work. Steidl: Göttingen, 2014.

Chéroux, Clément (ed.). Walker Evans. Exhibition catalogue. Editions du Centre Pompidou: Paris, 2017a.

---. "L'art de l'oxymore. Le style vernaculaire de Walker Evans". In Walker Evans. Exhibition catalogue. Editions du Centre Pompidou: Paris, 2017b, pp. 9-14.

Evans, Walker. Le Secret de la photographie. Entretien avec Leslie Katz. Text established by Anne Bertrand (translation by Bernard Hœpffner). Editions du Centre Pompidou: Paris, 2017.

Katz, Leslie. "Interview with Walker Evans”. Art in America, March-April 1971, pp. 82-89.

Exhibition catalogue

Chéroux, Clément (ed.). Walker Evans. Editions du Centre Pompidou: Paris, 2017.

The catalogue comes with Foreword by Serge Lasvignes, Preface by Bernard Blistène and essays by Clément Chéroux, Jerry L Thompson, Jeff L Rosenheim, Julie Jones, David Campany, Anne Bertrand, Didier Ottinger, Svetlana Alpers, and a long quote (also pasted in the final room in the exhibition space) from Walker Evans, as well as a biography, a (generous) selected bibliography and the list of all the exhibits.

ISBN 978-2-84426-765-8

\section{NOTES}

1. In reference to the first heading in Campany (2014: 9).

2. The exhibition was also supported by the Terra Foundation for American Art.

3. For a review of the exhibition in Arles in 2015, see https://miranda.revues.org/8411.

4. Bertrand (2017: 41) reports that Lesley Baier curated an exhibition in 1979 called "Walker Evans at Fortune", at the Wellesley College Museum (Wellesley, Massachusetts). There was virtually no academic interest in this body of work until the 2010s.

5. This revealing long interview was translated by Bernard Hœpffner for the first time into French and edited on the occasion of the exhibition, as Walker Evans. Le Secret de la photographie. Entretien avec Leslie Katz. The French edition was established by Anne Bertrand for the Centre national d'art et de culture Georges Pompidou, in 2017. The volume also includes a critical introduction by Anne Bertrand and a facsimile of the original article in English, making it a particularly precious bilingual edition of sorts. Indeed, citations in English in the present review come from this facsimile of the original and is henceforth referenced independently as Katz (1971). I would like to thank Emeline Jouve, of Champollion University, Albi, for offering me a copy as a birthday present in advance of my trip to the museum! 
6. I have essentially followed the English texts pasted on the walls in the exhibition space, but these texts derive extensively from the introductory essay in French by Chéroux (Chéroux 2017b).

7. Walker Evans, Anonymous, curated by David Campany, Jean-Paul Deridder and Sam Stourdzé, and presented at Les Rencontres de la Photographie in Arles, 6 July-20 September 2015, was first presented in France at the Pôle Image, Haute-Normandie, in Rouen between 13 March and 9 May 2015 and had been shown during the Krakow Photomonth, 15 May-15 June 2014 and at the FotoMuseum Provincie Antwerpen between 27 June and 11 November 2014 and has kept travelling subsequently.

8. See Bertrand (2017: 39) for a detailed description of what can be known about his time in France and what literary impacts he could pick up in Paris.

9. Mentioned in a footnote to the French translation of Evans' 1971 interview (Evans 2017: 38, fn 11).

10. It was published in Alhambra, vol.1, no. 3 (1929), pp. 34-35, 46. The same issue published a first photograph of his, "New York in the making".

INDEX

Subjects: Photography

Mots-clés: Walker Evans (1903-1975), style vernaculaire, exposition rétrospective, Centre Georges Pompidou

Keywords: Walker Evans (1903-1975), vernacular style, retrospective exhibition, Centre Georges Pompidou

\section{AUTHORS}

\section{DANIEL HUBER}

Maître de conférences

Université de Toulouse

daniel.huber@univ-tlse2.fr 